\title{
A New Leaf Blotch Disease of Sudangrass Caused by Pantoea ananas and Pantoea stewartii
}

\author{
H. R. Azad, Research Associate, Department of Plant Pathology, University of California, Riverside 92521; G. J. \\ Holmes, Extension Plant Pathologist, Department of Plant Pathology, North Carolina State University, Raleigh \\ 27695; and D. A. Cooksey, Professor, Department of Plant Pathology, University of California, Riverside 92521
}

\begin{abstract}
Azad, H. R., Holmes, G. J., and Cooksey, D. A. 2000. A new leaf blotch disease of sudangrass caused by Pantoea ananas and Pantoea stewartii. Plant Dis. 84:973-979.

An unreported disease of sudangrass (Sorghum sudanense) was observed in commercial fields in Imperial Valley of California. Symptoms included light-colored necrotic streaks, and white or tan irregular blotches, often associated with reddish purple to dark brown margins. Pantoea ananas was consistently isolated from the blotches with reddish margins, while Pantoea stewartii or mixtures of both species were isolated from necrotic streaks without reddish margins. Fourteen seed samples harvested in different locations were assayed and found to be 0.0 to $3.6 \%$ infested with $P$. ananas. Seed transmission may be a means by which the pathogen is introduced. Symptoms in inoculated plants appeared as early as 2 and as late as 20 days after inoculation, depending on the inoculum level, methods of inoculation, temperature, and available moisture. The initial symptoms caused by inoculations with both bacteria were similar, but as symptoms progressed, $P$. ananas was associated with white streaks or irregular necrotic blotches often surrounded by a reddish or purplish hue. P. stewartii was associated with lightcolored necrotic streaks. A synergistic or antagonistic relationship was not observed between the two pathogens in co-inoculations. In host range studies, both bacteria caused disease on sorghum and sudangrass at similar levels of severity. $P$. ananas was also pathogenic on corn and oat. P. stewartii from sudangrass was pathogenic on corn but did not cause wilting that was observed with Stewart's wilt strains of $P$. stewartii from corn. The sudangrass strains of $P$. stewartii also infected oat and triticale, while the Stewart's wilt strains did not. Both $P$. ananas and $P$. stewartii from sudangrass grew at relatively high temperatures $\left(43\right.$ and $37^{\circ} \mathrm{C}$, respectively) and caused disease at elevated temperatures and conditions of relative humidity similar to those in the Imperial Valley during late summer when epidemics of the disease were common.
\end{abstract}

Sudangrass (Sorghum sudanense) is an important hay crop in the Imperial Valley of California. In 1998, there were 70,000 acres, valued at nearly $\$ 34$ million. Sudangrass thrives under the extreme summer heat in the low desert and gives field crop and vegetable growers an excellent rotation option between spring and fall crops. Approximately $90 \%$ of the crop is exported to Japan where it is used as roughage in the diet of dairy cattle.

Typically, sudangrass foliage in Imperial Valley during the last several years exhibited a variety of chloroses and necroses that were more pronounced near the leaf tip and increased in severity as the growing season progressed from April to September. Most growers attributed the condition to abiotic factors (e.g., nutrient stress, extreme heat, wind, etc.) because symptoms were widespread and became more severe

Corresponding author: D. A. Cooksey

E-mail: cooksey@ucrac1.ucr.edu

Accepted for publication 19 May 2000.

Publication no. D-2000-0710-01R

(C) 2000 The American Phytopathological Society as summer temperatures and humidity rose. However, symptoms were typical of a disease, including light-colored necrotic streaks and white or tan blotches, often associated with reddish purple to dark brown margins. The severity of symptoms also varied greatly from one field to another. This report describes the isolation and confirmation of two bacteria, Pantoea ananas and Pantoea stewartii, as causal agents of this unreported disease. An abstract has been published (2).

\section{MATERIALS AND METHODS}

Isolation of causal agent. One hundred fifty-one diseased samples were collected from 151 different fields throughout the Imperial Valley between March and October 1996 . Tissue sections $(5 \times 5 \mathrm{~mm})$ from at least one leaf lesion from each field sample were placed on a sterile microscope slide in $0.1 \mathrm{ml}$ of sterile distilled water and macerated with a razor blade. The macerated tissue was covered with a glass cover slip and examined for bacterial streaming with a phase contrast microscope. Cover slips were then removed and the remaining suspensions were streaked onto mannitolglutamate-yeast extract (MGY) (20), yeast extract-dextrose-calcium carbonate (YDC)
(38), Tween (27), and Miller-Schroth (MS) (29) media. After the first 10 to 15 isolations, subsequent isolations were made on YDC plates only. This procedure also was used to isolate bacteria from inoculated leaves.

Identification of bacteria. Selected standard determinative tests were performed on 40 bacterial strains from sudangrass fields and 8 reference strains as positive and negative controls. The reference strains were $P$. agglomerans 0485-19 (ATCC 13329) and 0585-4 (isolated as an epiphyte from pepper in our laboratory); $P$. stewartii SW2 and SS104 (received from David L. Coplin, Ohio State University, Columbus); Erwinia amylovora 0693-22, E. carotovora subsp. carotovora 0395-5, Pseudomonas syringae pv. syringae 0584-6 (from culture collection in our laboratory); and E. chrysanthemi D1 (35). Cultural and morphological properties were determined on YDC plates. Cell morphology was recorded from light microscopy observations of Gram-stained smear preparations (1). Flagellation was determined by light microscopy following the methods of Blenden and Goldberg (6). Physiological and biochemical properties and carbon source utilization were tested by the methods described elsewhere $(12,14,18,22-24,30)$. Carbon source utilization profiles were also determined on Biolog GN microplates (Biolog, Inc., Hayward, CA). The Biolog microplates were visually read and the results were manually entered into the computer for comparison. Five strains of each colony type from sudangrass (see Results) and the reference strains were cultured on trypticase soy broth agar at $28^{\circ} \mathrm{C}$ for 24 to $48 \mathrm{~h}$. Fatty acid methyl esters were extracted by a standard method (33). Fatty acids were analyzed with a Sherlock Microbial Identification System (MIDI Inc., Newark, DE) that is composed of an automated gas chromatograph (GC 6890 Hewlett-Packard, Palo Alto, CA 94304) fitted with a $25 \mathrm{~m} \times 0.2 \mathrm{~mm}$, phenyl methyl, silicone-fused silica capillary column; an HP 7673 automatic sampler; and HP Chem Station Software (33). The analysis included an assessment of the degree of similarity of fatty acid composition.

Plant inoculations. Sudangrass was inoculated with a strain of $P$. ananas (069616) or P. stewartii (0696-17) by five methods and three plant growth conditions each. 
Both strains were isolated from sudangrass grown in Imperial Valley in 1996. Bacterial colonies were grown on YDC agar for 24 to $48 \mathrm{~h}$ at $28^{\circ} \mathrm{C}$ and suspended in sterile distilled water. The suspensions were diluted to approximately $10^{7}, 10^{9}$, or $10^{11} \mathrm{CFU} / \mathrm{ml}$, based on optical density readings with a Klett-Summerson colorimeter. Suspension concentrations were confirmed by dilution plating on YDC agar. The five inoculation methods used were: (i) suspensions sprayed onto leaf surfaces of sudangrass plants (cultivar Piper) until runoff with an aerosol-propelled sprayer; (ii) suspensions infiltrated into leaf tissues with a needleless syringe; (iii) suspensions injected into stems below the first leaf whorl; (iv) bacterial suspensions mixed with celite (an abrasive material, Sigma Chemical Co., St. Louis, MO) at the rate of $0.1 \%(\mathrm{~g} / \mathrm{vol})$ and applied to plant leaves with a soft cloth; and (v) bacterial colonies applied directly to wounds made with a 26-gauge needle in the epidermis of leaves and on the stems. Six pots (five plants each) were used for each of the five methods of inoculation, for a total of 30 pots (150 plants) per experiment. Of the six pots from each inoculation method, two were maintained on a greenhouse bench with natural light, ambient temperature between 19 and $22^{\circ} \mathrm{C}$, and relative humidity (RH) of 50 to $95 \%$. Two other pots from each inoculation method were placed in a growth chamber with a constant temperature of $32^{\circ} \mathrm{C}$, an $\mathrm{RH}$ that fluctuated between 40 and $65 \%$, and $12 \mathrm{~h}$ per day artificial light. The remaining two pots were placed in a growth chamber at a constant temperature of $32^{\circ} \mathrm{C}$ and $95 \% \mathrm{RH}$. Plants in this group also received artificial light for $12 \mathrm{~h} /$ day. The entire experiment was repeated five times. In all inoculation methods, bacterial suspensions contained $10^{7} \mathrm{CFU} / \mathrm{ml}$, except in the spray method in which the two cell concentrations were used, and sudangrass plants were 3 to 4 weeks old (4 to 5 leaf stage). An additional control pot (five plants) for each inoculation method and growth condition in each experiment was treated with water, a mixture of water and celite, or with $P$. agglomerans 0485-19 (ATCC 13329) and 0585-4 or P. stewartii SW2 and SS104. Each experiment lasted 6 weeks, and isolations were then made from several symptomatic leaves in each treatment.

In addition to the five inoculation methods of one experiment described above, three other experiments, with different parameters, were conducted. In the first experiment, the growth chamber temperature was set at $35^{\circ} \mathrm{C}$ (6 A.M. to 6 P.M.) and $22^{\circ} \mathrm{C}$ (6 P.M. to 6 A.M.) for $12 \mathrm{~h}$ each, but the RH was kept constant at $95 \%$. In the second experiment, the $10^{7} \mathrm{CFU} / \mathrm{ml}$ suspensions of both bacterial strains from sudangrass ( $P$. ananas and $P$. stewartii) were mixed in the ratio of $1: 1$ before inoculation. In the third experiment, a wet- ting agent, Silwet L-77 (OSI Specialties Inc., Sistersvilles, WV), was added to the bacterial suspensions $\left(10^{7} \mathrm{CFU} / \mathrm{ml}\right)$ at the rate of $0.1 \%$ (final concentration) before plants were spray inoculated. Methods of inoculation in the first and second experiments were the same as described above. Experiments two and three were conducted under the three growth conditions previously mentioned. One pot of five plants was used for each inoculation method and the three experiments were done twice.

Seed assay. Fourteen seed samples were assayed. Twelve samples were of seed produced in Imperial County, one was from northern California, and one was from Arizona. To isolate bacteria from seed, 1,000 seeds from each sample of the cultivar Piper were individually plated on MS medium. Plates were incubated at $28^{\circ} \mathrm{C}$ for 1 week. Strains recovered from each plate were purified by streaking single colonies on YDC medium at least four times. Strains were identified as described previously. Two isolates from each positive seed sample were used in pathogenicity tests. Bacterial suspensions $\left(10^{7} \mathrm{CFU} / \mathrm{ml}\right)$ were injected into sudangrass, and sorghum plants below the first leaf whorl or bacterial colonies were applied to needleinduced wounds on those plants.

Host range. A host range test was conducted either by injecting $10^{7} \mathrm{CFU} / \mathrm{ml}$ of bacterial suspensions below the first leaf whorl or by directly applying bacterial colonies to wounds in the stem of barley (Hordeum vulgare L. cv. Betzes), corn (Zea mays cv. honey-cream), oat (Avena sativa), rye (Secale cereale cv. Imperial), sorghum (Sorghum bicolor L. Moench cv. $\mathrm{N}-\mathrm{K}-737$ ), triticale (Triticosecale spp. cv. Juan), and wheat (Triticum aestivum L. cv. Yecora Rojo). The bacteria used in this test were $P$. ananas strain 0696-16 from sudangrass leaves, strain 0696-21 from sudangrass seeds, $P$. stewartii strain 0696-17 from sudangrass, strains SW2 and SS104 from corn, and $P$. agglomerans strains 0485-19 and 0585-4. Two pots (five plants each) were used for each cultivar in each inoculation method. Plants were 3 to 4 weeks old (4 to 5 leaf stage) at the time of inoculation. Inoculated plants were incubated under the three previously described growth conditions and observed for disease development during 6 weeks. The experiment was repeated twice.

Temperature range for growth in vitro. Five similar-size colonies of $P$. ananas 0696-16, 0696-21, and P. stewartii 0696-17 were suspended in $1 \mathrm{ml}$ sterile distilled water and $20 \mu \mathrm{l}$ of each suspension was streaked onto YDC plates and incubated at 5, 12, 15, 18, 21, 24, 27, 28, 30, 33, 35, 37, $40,41,43$, and $44^{\circ} \mathrm{C}$. Growth on each plate was recorded daily for 7 days.

Enzyme assay. Two strains of bacteria (0696-16 and 0696-17) from sudangrass plants and one strain from sudangrass seeds (0696-21) were streaked onto yeast
extract-Casamino acids (YC) plates (21) containing either $0.7 \%$ sodium polypectate or $1.0 \%$ carboxy methyl cellulose (CMC) and screened for production of pectate lyase or cellulase activity respectively as described by Vroemen et al. (35). Bacterial cells were also transferred by toothpick onto Triton X-100/glycerol medium of Braun and Rodrigues (8), based on the mineral salts of Zucker and Hankin (39). The medium was supplemented with $0.1 \%$ yeast extract, and $0.2 \%$ Remazol Brilliant Blue R-Xylan (RBB xylan) (Sigma, St. Louis, MO), and the $\mathrm{pH}$ was adjusted to 6.0 before sterilization. Endoxylanase activity was detected after $24 \mathrm{~h}$ incubation at $37^{\circ} \mathrm{C}$ by the method of Biely et al. (5). Erwinia chrysanthemi strain D1 (35) and $P$. agglomerans strains 0485-19 and 0585-4 were used as positive and negative controls, respectively.

Toxin assay. To determine the production of phytotoxic chemicals by the sudangrass pathogens, strains 0696-16 and 069617 were grown in a liquid induction medium (32) for 48 to $72 \mathrm{~h}$ at $28^{\circ} \mathrm{C}$ with shaking. Cells were collected by centrifugation and discarded. A portion of the supernatant was filtered through a $0.45-\mu \mathrm{m}$ Millipore filter. Another portion of the supernatant was passed through a 0.1 - or $0.2-\mu \mathrm{m}$ filter. Half-milliliter aliquots of the two filtrates and the original supernatant were injected into the stem of sudangrass, sorghum, and corn plants. The plants were kept under the three growth conditions described earlier and observed for any symptom development during one month.

\section{RESULTS}

Observation of disease symptoms in the field. Close examination of plants revealed several types of symptoms, which included: (i) linear, yellow to dark brown streaks with regular margins that paralleled veins and sometimes extended the length of the leaf (Fig. 1A); (ii) short to long irregular streaks in the leaves, which were straw colored to reddish brown and sometimes surrounded by a broad yellow halo; (iii) interveinal, elongated blotches, ranging from a few millimeters to a few centimeters parallel to the leaf veins, and white to tan in color, often with reddish purple to dark brown margins (Fig. 1B).

Streaks tended to coalesce along the width of the leaf to produce blotches covering most of the leaf, especially toward the leaf tips (Fig.1C and D). Water soaking of the tissue adjacent to a lesion was normally not observed.

Isolation and identification of causal agent. When lesions (at least 151; one from each field sample) were macerated in sterile distilled water and observed using phase-contrast microscopy, numerous rodshaped bacteria were observed streaming from leaf tissues. When suspensions from tissues were plated on MS and YDC plates, two colony types in the ratio of approxi- 

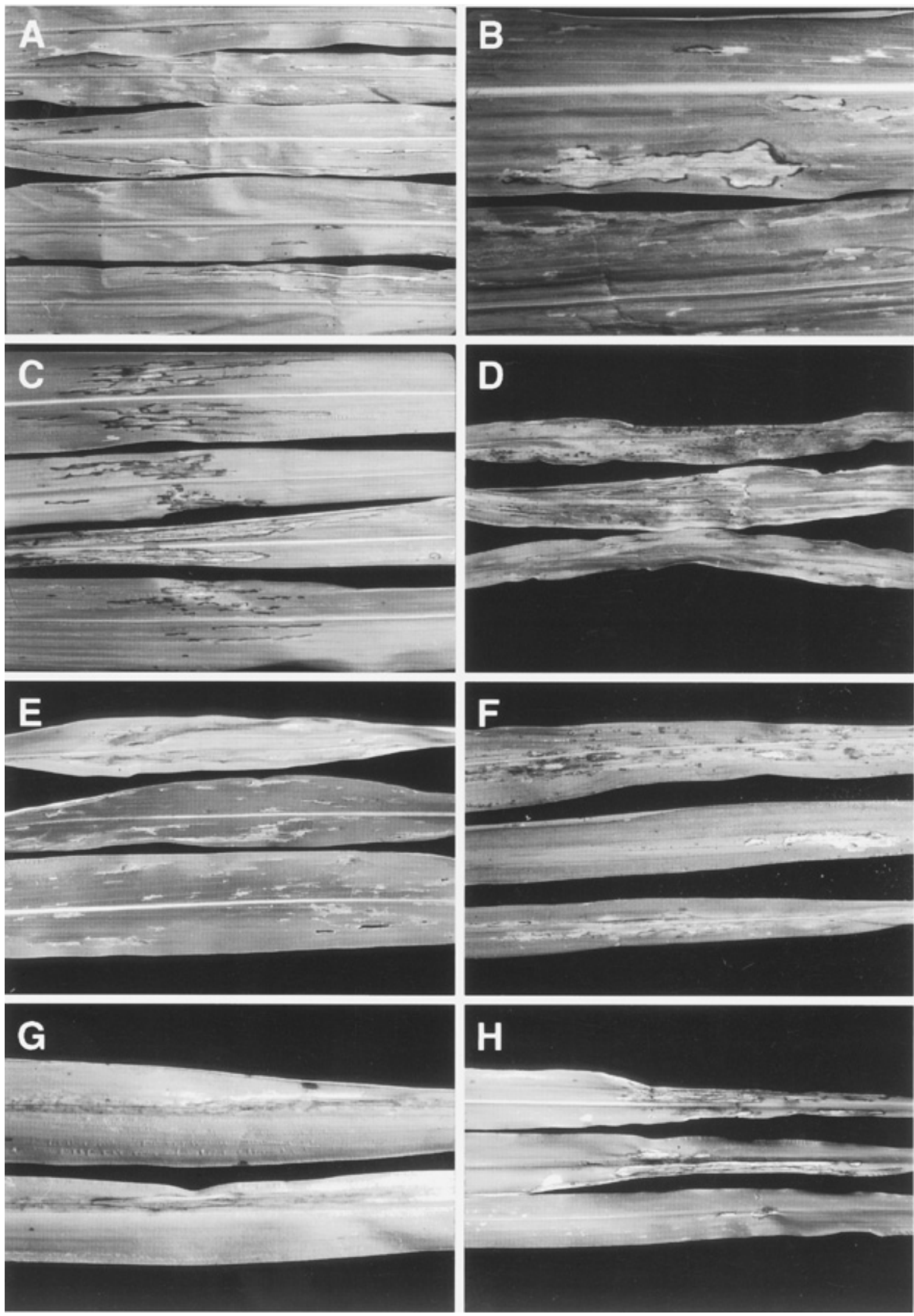

Fig. 1. Pantoea ananas and Pantoea stewartii and associated disease symptoms on sudangrass leaves. Symptoms from (A-D) natural infections in the field. Early symptoms from (E, middle and bottom) spray-inoculated plants with $P$. ananas in the growth chamber. Symptoms from (F) spray-inoculated plants with $P$. ananas 10 days after appearance. Symptoms from (E [top] and G) inoculations involving celite with $P$. ananas and $P$. stewartii, respectively, 10 days after inoculation. Spread of $(\mathbf{H})$ infection from the site of needle inoculations with $P$. ananas. 
mately 2:1 (two type 1/one type 2) were recovered consistently. On MS medium, which is selective and differential for bacteria in the Enterobacteriaceae, type 1 colonies were 1 to $3 \mathrm{~mm}$ in diameter, entire, circular, flat, umbonate, dull, yellow, and more restricted, but type 2 colonies were 1 to $5 \mathrm{~mm}$ in diameter, entire, circular to irregular, raised to convex, glistening with yellow-orange color. Strains purified of the first, smaller colony type (type 1 colony) were identified as $P$. ananas, and strains purified of the type 2 colony type (were identified as $P$. stewartii (Table 1). P. ananas strains were motile by peritrichous flagellation, but $P$. stewartii strains were nonmotile. In addition to the data presented in Table 1, all the strains had yellow pigmentation and were positive for anaerobic growth, mucoid growth on 5\% sucrose, growth on MacConkey agar, growth in 5\% $\mathrm{NaCl}$, catalase production, utilization of $\mathrm{L}$ arabinose, D-mannose, D-xylose, myoinositol, D-mannitol, D-ribose, and sucrose, but were negative for Gram stain, growth factor requirements, growth in $\mathrm{KCN}$ broth, oxidase, arginine dihydrolase, gas from Dglucose, and urease production. Identification of these bacteria as $P$. ananas and $P$. stewartii by selective determinative tests were confirmed by Biolog identification system and fatty acid profiles. P. stewartii on YDC was colorless at first, turning to pale yellow with age. Colonies were convex to dome shaped, shiny, and highly mucoid. Colonies of $P$. ananas on YDC were orange-yellow, 1 to $10 \mathrm{~mm}$ in diameter, first convex to dome shaped, rapidly becoming flat and sometimes with peripheral ridges. On MGY, both bacteria had small to medium size colonies with irregular margins. The colonies were raised, very mucoid, running, and had a creamy yellow color. Tween medium did not support the growth of either bacterium.

A total of 171 bacterial strains were isolated from different lesions on 135 samples of the 151 field samples assayed. One hundred fifteen of those strains were $P$. ananas and 62 strains were $P$. stewartii. Both bacteria co-existed on the same lesion of a number of samples. In contrast, neither bacterium was isolated from 16 samples. The classification of these 171 strains into $P$. ananas and $P$. stewartii was based solely on colony types on YDC plates. The majority of $P$. ananas was isolated from irregular blotches with dark and reddish margins, whereas the majority of $P$. stewartii was recovered from light-colored necrotic streaks.

Plant inoculations. When plants were spray-inoculated, infection and disease development were affected by the number of viable cells in the inoculum $\left(10^{7}, 10^{9}\right.$, or $10^{11} \mathrm{CFU} / \mathrm{ml}$ ) and the growth conditions.
Disease symptoms appeared on plants placed in the growth chamber at $32^{\circ} \mathrm{C}$ with variable RH (40 to 60\%) 7 days after inoculation with $P$. ananas and 11 days after inoculation with $P$. stewartii. Leaves developed small (1 to $2 \mathrm{~mm}$ ), white to reddish flecks or spots in veins as well as in interveinal and marginal areas (Fig. 1E middle and bottom). The lesions from both pathogens expanded over time to form long, necrotic to dark brown stripes and streaks ( $P$. stewartii) or large white to necrotic areas ( $P$. ananas), which coalesced and caused the collapse of the entire leaf within 15 to 25 days after lesions became visible (Fig. 1F). These white to necrotic areas often were surrounded by chlorotic halos or reddish to slightly purple margins (P. ananas) similar to what was observed with natural infection in the field. Symptoms appeared on plants in the growth chamber under constant RH (95\%) about the same time as plants under variable $\mathrm{RH}$, but the lesions expanded much more rapidly and plants grew faster under constant $\mathrm{RH}$. In the greenhouse, with a temperature 10 to 13 degrees lower than in the growth chambers, symptoms were not visible until 17 days after inoculation, and lesions did not expand beyond 1 to $2 \mathrm{~cm}$ in diameter.

When plants were inoculated by infiltration of bacterial suspensions into the leaves, by injection of suspensions into the

Table 1. Identification of bacterial strains from sudangrass as Pantoea ananas and Pantoea stewartii ${ }^{\mathrm{V}}$

\begin{tabular}{|c|c|c|c|c|c|c|c|}
\hline \multirow[b]{2}{*}{ Test } & \multicolumn{2}{|c|}{ Pantoea agglomerans } & \multicolumn{2}{|c|}{ Pantoea ananas } & \multicolumn{3}{|c|}{ Pantoea stewartii } \\
\hline & Reported $^{w}$ & Known strain $^{x}$ & Reported $^{\mathrm{w}}$ & $\begin{array}{l}\text { Sudangrass } \\
\text { strain }^{y}\end{array}$ & Reported $^{\mathrm{w}}$ & $\begin{array}{l}\text { Known } \\
\text { strain }^{z}\end{array}$ & $\begin{array}{c}\text { Sudangrass } \\
\text { strain }^{y}\end{array}$ \\
\hline $\mathrm{H}_{2} \mathrm{~S}$ production & + & + & \pm & - & - & - & - \\
\hline Hypersensitivity on tobacco & - & - & NR & + & NR & - & - \\
\hline Potato rot & - & - & NR & - & NR & - & - \\
\hline Gelatin liquefaction & \pm & $+/ \mathrm{w}$ & \pm & + & - & - & - \\
\hline Nitrate reduction & + & + & \pm & - & - & - & - \\
\hline Indole & - & - & + & + & - & - & - \\
\hline Voges Proskauer & + & w/- & + & + & - & - & - \\
\hline Methyl red & \pm & w/- & NR & - & NR & \pm & - \\
\hline Phenylalanine deaminase & + & + & - & - & - & - & - \\
\hline \multicolumn{8}{|l|}{ Utilization of: } \\
\hline Acetate & NR & - & NR & $\mathrm{w}$ & NR & - & - \\
\hline Citrate, glycerol, lactose, melibiose & \pm & + & + & + & + & + & + \\
\hline Malonate & \pm & + & - & - & - & - & - \\
\hline Maleate, molybdate, propionate & NR & - & NR & - & NR & - & - \\
\hline Tartrate & \pm & \pm & + & - & + & - & - \\
\hline D+Tartrate, D-Tartrate & NR & \pm & - & - & NR & - & - \\
\hline meso-Tartrate & NR & + & + & + & NR & + & + \\
\hline D-Arabinose & + & $+/ \mathrm{w}$ & + & $+/ \mathrm{w}$ & - & - & - \\
\hline D-Cellobiose & \pm & + & + & + & \pm & - & - \\
\hline D-Fructose & NR & + & NR & + & NR & + & + \\
\hline D-Galactose, D-glucose & + & + & + & + & NR & + & + \\
\hline Maltose & \pm & + & + & + & - & - & - \\
\hline Raffinose & \pm & \pm & + & + & + & + & - \\
\hline L-Rhamnose & + & + & \pm & - & - & - & - \\
\hline Trehalose & + & + & + & + & + & + & - \\
\hline D-Arabitol & \pm & - & \pm & - & NR & - & - \\
\hline Inositol & + & + & + & + & - & w & $+/ \mathrm{w}$ \\
\hline D-Sorbitol & \pm & - & + & - & + & - & - \\
\hline
\end{tabular}

${ }^{v}$ Symbols: $+=$ positive reaction within 1 to 8 days of incubation at $28^{\circ} \mathrm{C} ;-=$ no reaction; $\pm=$ some strains positive and some strains negative; $\mathrm{w}=$ weak reaction; and $\mathrm{NR}=$ not reported.

${ }^{\mathrm{w}}$ Data as published $(4,11,13,16,17,24,30,35)$.

${ }^{x}$ Known P. agglomerans strains 0485-19 (ATCC 13329) and 0585-4.

y Results from 20 strains of $P$. ananas and 20 strains of $P$. stewartii isolated from sudangrass in the present study.

${ }^{\mathrm{z}}$ Known strains SW2 and SS104 of P. stewartii from corn (David L. Coplin, Ohio State University, Columbus). 
plant stems, by direct application of bacterial colonies to needle induced wounds, or by application of suspensions containing celite, infection was rapid. Symptoms appeared 2 to 3 days after inoculation of plants in growth chambers, and after 6 to 7 days after plants in the greenhouse were inoculated. In the presence of celite, symptoms from both pathogens were irregular, wide, and long, white to necrotic streaks or blotches (Fig. 1E [top] and G). With the other three inoculation methods, symptoms were narrow (1 to $2 \mathrm{~mm}$ wide) yellow to dark brown streaks mainly in veins originating from the inoculation points and extending in both directions, but mostly toward the leaf tips. The streaks gradually expanded along the width of the leaves and formed wide streaks, which eventually killed the tissues (Fig. 1H).

With all inoculation methods, the initial symptoms caused by both bacteria were similar. As the disease progressed, symptoms caused by each bacterium became more differentiated. $P$. ananas was associated with white streaks or irregular white to tan blotches often with a reddish or purplish margin, whereas $P$. stewartii resulted in light-colored necrotic streaks. Secondary infection by either bacterium was not observed. Both pathogens were isolated from selected, inoculated, symptomatic plants, and comparative biological tests confirmed that strains 0696-16 and 0696-17 had been re-isolated.

Control plants and those inoculated with P. agglomerans strains 0485-19 and 0585-4 remained symptomless. $P$. stewartii SW2 was virulent on sudangrass, with only a few short streaks observed on plants in the greenhouse and in the growth chamber with $95 \%$ RH. P. stewartii strain SS104 failed to incite any symptoms on sudangrass under the three growth conditions tested.

In the growth chamber with a temperature of $35^{\circ} \mathrm{C}$ during the day and $22^{\circ} \mathrm{C}$ at night, the $\mathrm{RH}$ was high enough that free water was always present on plants. In the presence of free water, the disease severity for both bacteria was less than that under dry or humid conditions. In addition, $P$. ananas was less affected by free water than was $P$. stewartii. Reduced disease severity may be due to free water or low night temperature.

When plants were inoculated by spray and infiltration methods, with a mixture of the two bacteria, no synergistic or antagonistic relationship was observed. Both bacteria were able to infect the plants and cause disease. Both bacteria were isolated from these lesions.

The wetting agent, Silwet L-77, considerably enhanced coverage of plants with inoculum and also increased infection and symptom development. However, in noninoculated controls, it caused injuries to leaf tissues in the form of necrotic patches similar to those produced by $P$. ananas and P. stewartii.

Seed assay. When sudangrass seeds were plated directly onto MS medium, different levels of infestation with $P$. ananas were observed for different seed samples. P. stewartii was not recovered from seeds. Pathogens were not detected from five of the 14 seed lots assayed. The level of infestation with $P$. ananas in the other nine seed lots was $0.09,0.19,0.23$, $0.43,0.71,0.88,1.17,2.88$, and $3.6 \%$. P. ananas grew from contaminated seeds after 2 to 3 days incubation at $28^{\circ} \mathrm{C}$. All 18 seed isolates of $P$. ananas (two from each positive seed lot) were pathogenic when plants were injected with bacterial suspensions $\left(10^{7} \mathrm{CFU} / \mathrm{ml}\right)$, or bacterial colonies were applied to needle-induced wounds on sudangrass and sorghum plants. Symptoms appeared 7 to 10 days after inoculation.

Host range. $P$. ananas isolated from sudangrass leaves (0696-16) and seeds (0696-21) was pathogenic on oat and corn (Table 2) but was nonpathogenic on barley, rye, triticale, and wheat. In oat, $P$. ananas caused a few short $(1$ to $5 \mathrm{~cm})$ necrotic streaks at $32^{\circ} \mathrm{C}$ and $95 \% \mathrm{RH}$. In corn, chlorosis occurred in leaves, which was more pronounced in veins. The bacterium was recovered from those veins some distance $(10$ to $20 \mathrm{~cm})$ away from the inoculation points. $P$. stewartii from sudangrass (0696-17) did not cause disease in barley, rye, or wheat but infected oat and triticale at $32^{\circ} \mathrm{C}$ regardless of humidity conditions (Table 2). The symptoms on these plants consisted of short, necrotic lesions and streaks. In corn, this strain caused long, dark, brown streaks, which widened into dark, necrotic streaks similar to the type of symptoms observed on sudangrass. The three sudangrass strains (0696-16, 069621, and 0696-17) were also pathogenic on sorghum. The type of symptoms and the severity of the disease caused by these strains on sorghum and sudangrass were similar (Table 2). P. stewartii SW2 and $\mathrm{SS} 104$ did not cause any symptoms in barley, oat, rye, triticale, or wheat, but in corn, severe wilting and death or necrotic leaf streaks were observed. In sorghum, strains SW2 and SS104 of P. stewartii caused a few short streaks. $P$. agglomerans strains 0485-19 and 0585-4 were nonpathogenic on all plants tested (Table 2).

Temperature range for growth. $P$. ananas grew faster than $P$. stewartii in culture. After $24 \mathrm{~h}$ at $28^{\circ} \mathrm{C}$, colonies of $P$. ananas reached 1 to $3 \mathrm{~mm}$ in diameter, while colonies of $P$. stewartii were visible only after $48 \mathrm{~h}$ of incubation at $28^{\circ} \mathrm{C}$. $P$. ananas also grew at higher temperatures than $P$. stewartii. $P$. ananas grew at the tested temperatures between 12 and $43^{\circ} \mathrm{C}$, but it did not grow at 5 and $44^{\circ} \mathrm{C}$. $P$. stewartii grew at temperatures from 12 to $37^{\circ} \mathrm{C}$ but did not grow at 5 or $40^{\circ} \mathrm{C}$.

Enzyme and toxin assays. All strains from sudangrass (plants and seeds) and $P$. agglomerans strains 0485-19 and 0585-4 were negative for endoxylanase and pectate lyase activity. $P$. ananas and $P$. stewartii from sudangrass were positive for cellulase activity, while $P$. agglomerans strains were negative. E. chrysanthemi strain D1 was positive for each of these enzymes. Culture supernatant fluids from sudangrass strains passed through 0.1 - or 0.2 - and $0.45-\mu \mathrm{m}$ filters failed to incite any symptoms in sudangrass, sorghum, or corn plants under any growth condition tested.

\section{DISCUSSION}

$P$. ananas was first described by Serrano in 1928 as the causal agent of fruitlet rot of pineapple (31). Since then, it has been reported in association with other plants $(3,9,10,15,19,26,36,37)$. $P$. ananas as described by Serrano was indistinguishable from $P$. agglomerans and, therefore, was classified as such by Lelliott (25). In the first edition of Bergey's Manual of Systematic Bacteriology, Volume 1, the species designation $P$. ananas Serrano was con-

Table 2. Pathogenicity of strains of Pantoea ananas, Pantoea stewartii, and Pantoea agglomerans on various Gramineae hosts

\begin{tabular}{|c|c|c|c|c|c|c|c|}
\hline \multirow[b]{2}{*}{ Host } & \multicolumn{2}{|c|}{ Pantoea ananas } & \multicolumn{3}{|c|}{ Pantoea stewartii } & \multicolumn{2}{|c|}{ Pantoea agglomerans } \\
\hline & 0696-16 & 0696-21 & 0696-17 & SW2 & SS104 & 0485-19 & 0585-4 \\
\hline Sorghum & $+++^{\mathrm{z}}$ & ++ & ++ & + & + & - & - \\
\hline Corn & + & + & ++ & ++++ & ++ & - & - \\
\hline Oat & + & + & + & - & - & - & - \\
\hline Triticale & - & - & + & - & - & - & - \\
\hline Barley & - & - & - & - & - & - & - \\
\hline Rye & - & - & - & - & - & - & - \\
\hline Wheat & - & - & - & - & - & - & - \\
\hline
\end{tabular}

$\mathrm{z}_{-}=$No reaction; $+=$short $(1$ to $5 \mathrm{~cm})$ stripes and streaks, necrotic lesion, or vein chlorosis; $++=$ mild necrotic lesion, stripes and streaks; $+++=$ severe necrotic lesion, stripes and streaks; $++++=$ the same as +++ with wilting. 
structed to accommodate the only member of the $P$. agglomerans group that was phytopathogenic. Later studies $(4,13,16,17,23$, $28,34)$ have shown that $P$. ananas is distinct from $P$. agglomerans based on pathogenicity and the indole test. Our morphological, biochemical, and physiological tests, as well as fatty acid profiles and Biolog data, support this distinction. The extension of the host range of $P$. ananas to sudangrass also confirms its distinct taxonomic position.

In pathogenicity tests in which plants were injured before or during inoculation, visible symptoms developed several days earlier than on plants that were inoculated by spraying. Natural wounding of sudangrass may occur in the Imperial Valley from wind-blown sand, insect feeding, or from plant-to-plant contact during high winds. If $P$. ananas resides epiphytically on sudangrass foliage as it does on rice (36), such wounding could be an important factor in pathogen entry and development of the widespread epidemics observed.

Daily high temperatures in the Imperial Valley during sudangrass production frequently reach $47^{\circ} \mathrm{C}$ and can remain above $38^{\circ} \mathrm{C}$ for several days. Humidity is generally low, but rises to 40 to $55 \%$ in late summer during peak sudangrass production. The sudangrass pathogens grew at relatively high temperatures in vitro (37 and $43^{\circ} \mathrm{C}$ ), and infection of sudangrass was greater in growth chambers held at $32^{\circ} \mathrm{C}$ than in the greenhouse with temperatures ranging between 19 and $22^{\circ} \mathrm{C}$. High $\mathrm{RH}$ enhanced symptom development in growth chamber experiments, but a RH of 40 to $60 \%$ was sufficient for the development of symptoms typical of those observed in the field.

In host range studies, $P$. ananas did not cause extensive disease in other hosts except sorghum. The types and severity of symptoms caused by this bacterium on sorghum and sudangrass were similar. $P$. stewartii from sudangrass also caused symptoms on sorghum that were indistinguishable from those caused on sudangrass, and it caused similar symptoms on corn. However, Stewart's wilt strains of $P$. stewartii from corn caused more severe symptoms on corn, including wilting. Stewart's wilt strains have been reported previously to infect sorghum and sudangrass $(7,13)$, but in our experiments, they were less virulent on those hosts than the sudangrass strains. P. stewartii from sudangrass also caused symptoms on oat and triticale, but the Stewart's wilt strains of $P$. stewartii did not, suggesting differences in host specificity between sudangrass and Stewart's wilt strains.

The extent to which the described disease complex affects sudangrass yield and quality has not been measured. Disease severity can vary greatly between fields, but most fields in Imperial Valley have been affected during epidemics. In severe cases, blighted foliage can reach $50 \%$ or more of total leaf area. Further discoloration of foliage that is observed occasionally after harvest may be due to these bacteria or by predisposition of infected foliage to other decay organisms.

\section{LITERATURE CITED}

1. Annette, E., Bazows, H. A., Hausller, W. J., and Shadomy, H. J. 1985. Manual of Clinical Microbiology. Fourth Ed. American Society for Microbiology, Washington, DC.

2. Azad, H. R., Holmes, G. J., and Cooksey, D. A. 1997. A new leaf blotch disease of Sudan grass caused by Pantoea ananas and Pantoea stewartii. Phytopathology (Abstr.) 87:S5

3. Azegami, K., Ozaki, K., Matsuda, A., and Ohata, K. 1983. Bacterial palea browning, a new disease caused by Erwinia herbicola. Nogyo Gijutsu Kenkyujo Hokoku C37:1-12.

4. Beji, A., Mergaert, J., Gavini, F., Mielcarek, C., Izard, D., Kersters, K., Leclerc, H., and De Ley, J. 1988. Subjective synonymy of Erwinia herbicola, Erwinia melletiae, and Enterobacter agglomerans and redefinition of the taxon by genotypic and phenotypic data. Int. J. Syst. Bacteriol. 38:77-88.

5. Biely, P., Markovic, O., and Mislovicova, D. 1985. Sensitive detection of endo-1,4- $\beta$ - glucanases and endo-1,4- $\beta$-xylanases in gels. Anal. Biochem. 144:147-151.

6. Blenden, P. C., and Goldberg, H. S. 1965. Silver impregnation stain for Leptospira flagella. J. Bacteriol. 89:899-900.

7. Bradbury, J. F. 1967. Erwinia stewartii. Descriptions of pathogenic fungi and bacteria No. 123. Commonwealth Mycological Institute, Surrey, England.

8. Braun, E. J., and Rodrigues, C. A. 1993. Purification and properties of an endoxylanase from a corn stalk rot strain of Erwinia chrysanthemi. Phytopathology 83:332-338.

9. Bruton, B. D., Wells, J. M., Lester, G. E., and Patterson, C. L. 1991. Pathogenicity and characterization of Erwinia ananas causing a postharvest disease of cantaloup fruit. Plant Dis. 75:180-183

10. Ceponis. M. J., Wells, J. M., and Cappellini, R. A. 1985. Bacterial brown spot of honeydew melons. Hort. Sci. 20:302-303.

11. Cooksey, D. A. 1986. Galls of Gypsophila paniculata caused by Erwinia herbicola. Plant Dis. 70:464-468.

12. Cuppels, D., and Kelman, A. 1974. Evaluation of selective media for isolation of softrot bacteria from soil and plant tissue. Phytopathology 64:468-475.

13. Dye, D. W. 1983. Erwinia: The "Amylovora" and "Herbicola" groups. Pages 67-86 in: Plant Bacterial Diseases, a Diagnostic Guide. P. C. Fahy and G. J. Persley, eds. Academic Press, New York.

14. Edwards, P. R., and Ewing, W. H. 1962. Identification of Enterobacteriaceae. Burgess Publishing Co., Minneapolis, MN.

15. Elliott, C. 1951. Manual of Bacterial Plant Pathogens. 2nd Ed. Chronica Botanica, Waltham, MA.

16. Ewing, W. H., and Fife, M. A. 1972. Enterobacter agglomerans (Beijerinck) comb. nov. (Herbicola-Lathyri Bacteria). Int. J. Syst. Bacteriol. 22:4-11.

17. Gavini, F., Mergaert, J., Beji, A., Mielcarek, C., Izard, D., Kersters, K., and De Ley, J. 1989. Transfer of Enterobacter agglomerans (Beijerinck 1888) Ewing and Fife 1972 to Pantoea gen. nov. as Pantoea agglomerans comb. nov. and description of Pantoea dispersa sp. nov. Int. J. Syst. Bacteriol. 39:337345.

18. Gerhardt, P., Murray, R. G. E., Costilow, R. N., Nester, E. W., Wood, W. A., Krieg, N. R., and Phillips, G. B., ed. 1981. Manual of Methods for General Bacteriology. American Society for Microbiology, Washington, DC.

19. Gitaitis, R. D., and Gay, J. D. 1997. First report of a leaf blight, seed stalk rot, and bulb decay of onion by Pantoea ananas in Georgia. Plant Dis. 81:1096.

20. Keane, P. J., Kerr, A., and New, P. B. 1970. Crown gall of stone fruit. II. Identification and nomenclature of Agrobacterium isolates. Aust. J. Biol. Sci. 23:585-595.

21. Keen, N. T., Dahlbeck, D., Staskawicz, B. and Belser, W. 1984. Molecular cloning of pectate lyase genes from Erwinia chrysanthemi and their expression in Escherichia coli. J. Bacteriol. 159:825-831.

22. Klement, Z. 1963. Rapid detection of pathogenicity of phytopathogenic pseudomonads. Nature (Lond.) 199:299-300.

23. Krieg, N. R., and Holt, J. G., eds. 1984. Bergey's Manual of Systematic Bacteriology. Vol. 1. Williams and Wilkins, Baltimore, MD.

24. Lai, M., and Haas, B. 1973. Reaction of cowpea seedlings to phytopathogenic bacteria. Phytopathology 63:1099-1103.

25. Lelliott, R. A. 1974. Genus XII. Erwinia Winslow Broadhurst, Buchanan, Krumwiede, Rogers and Smith 1920. Pages 332-240 in Bergey's Manual of Determinative Bacteriology, 8th ed. R. E. Buchanan and N. E. Gibbons, eds. The Williams and Wilkins Co., Baltimore.

26. Limura, K., and Hosona, A. 1996. Biochemical characteristics of Enterobacter agglomerans and related strains found in buckwheat seeds. Int. J. Food Microbiol. 30:243-253.

27. McGuire, R. G., Jones, J. B., and Sasser, M. 1986. Tween media for semiselective isolation of Xanthomonas campestris pv. vesicatoria from soil and plant material. Plant Dis. 70:887-891.

28. Mergaert, J., Verdonck, L., and Kersters, K. 1993. Transfer of Erwinia ananas (synonym, Erwinia uredovora) and Erwinia stewartii to the genus Pantoea Emend. as Pantoea ananas (Serrano 1928) comb. Nov., and Pantoea stewartii (Smith 1898) comb. Nov., respectively, and description of Pantoea stewartil subsp. indologenes subsp. Nov. Int. J. Syst. Bacteriol. 43:162-173.

29. Miller, T. D., and Schroth, M. N. 1972 Monitoring the epiphytic population of $\mathrm{Er}$ winia amylovora on pear with a selective medium. Phytopathology 62:1175-1182.

30. Schaad, N. W., ed. 1988. Laboratory Guide for Identification of Plant Pathogenic Bacteria. American Phytopathological Society, St Paul, MN.

31. Serrano, F. B. 1928. Bacterial fruitlet brownrot of pineapple in the Philippines. Philipp. J. Sci. 36:271-305.

32. Shen, H., and Keen, N. T. 1993. Characterization of the promoter of avirulence gene D from Pseudomonas syringae pv. tomato. J. Bacteriol. 175:5916-5924.

33. Stead, D. E. 1988. Identification of bacteria by computer-assisted fatty acid profiling. Acta Hortic. 225:39-46

34. Verdonck, L., Mergaert, J., Rijckaert, C. Swings, J., Kersters, K., and De Ley, J. 1987. Genus Erwinia: Numerical analysis of phenotypic features. Int. J. Syst. Bacteriol. 37:418.

35. Vroemen, S., Heldens, J., Boyd, C., Henrissat, B., and Keen, N. T. 1995. Cloning and characterization of the bgxA gene from Erwinia chrysanthemi D1 which encodes a $\beta$-glucosidase/xylosidase enzyme. Mol. Gen. Genet. 246:465-477

36. Watanabe, K., Kawakita, H., and Sato, M. 1996. Epiphytic bacterium, Erwinia ananas, commonly isolated from rice plants and brown plant hoppers (Nilaparvata lugens) in 
hopperburn patches. Appl. Entomol. Zool. 31:459-462.

honeydew melons. Phytopathology 77:511514.

37. Wells, J. M., Sheng, W. S., Ceponis, M. J., and Chen, T. A. 1987. Isolation and characterization of strains of Erwinia ananas from
38. Wilson, E. E., Zeitoun, F. M., and Fredrickson, D. L. 1967. Bacterial phloem canker, a new disease of Persian walnut trees. Phyto- pathology 57:618-621.

39. Zucker, M., and Hankin, L. 1970. Regulation of pectate lyase synthesis in Pseudomonas fluorescens and Erwinia carotovora. J. Bacteriol. 104:13-18. 